\title{
STRATEGI RADIO REPUBLIK INDONESIA (RRI) PEKANBARU DALAM MENYAMPAIKAN PROGRAM SIARAN DAKWAH
}

\author{
Imron Rosidi dan Rizal Zain \\ Fakultas Dakwah dan Komunikasi, UIN Suska Riau \\ Email: imronrosidi@gmail.com
}

\begin{abstract}
Abstrak
Penelitian ini dilatarbelakangi peran radio sebagai media informasi dalam menyampaikan pesan-pesan dakwah di tanah air khususnya di Pekanbaru.Penelitian ini dilakukan di Radio Republik Indonesia (RRI) Pekanbaru.Permasalahan dalam penelitian ini adalah bagaimana strategi RRI dalam menyampaikan program siaran dakwah terhadap pemirsa dikarenakan RRI merupakan Radio bersifat media publik (milik pemerintah).Tujuan dalam penelitian ini adalah untuk mengetahui strategi yang digunakan oleh RRI Pekanbaru dalam menyampaikan program siaran dakwah.Metodologi dalam penelitian ini berjenis deskriptif dengan menggunakan pendekatan kualitatif.Subjek dalam penelitian ini adalah pimpinan beserta pegawai strukturalRRI Pekanbaru sedangkan objeknya adalah strategi yang digunakan RRI Pekanbaru dalam menyampaikan program siaran dakwah. Informan dalam penlitian ini berjumlah 8 orang diantaranya satu orang Pimpinan, dua orang Penyiar, dua orang Da'i, dua orang Pemirsa dan satu Tokoh agama. Penelitian ini disusun dengan menggunakan kerangka pikir yang sistematis dengan menggunakan Model Deduktif. Adapun hasilpenelitian ini adalah RRI menggunakan tiga strategi yaitu pertama Srategi Perencanaandengan menetapkan tema dan topik yang ingin disampaikan, menetapkan penyiar serta menentukan jadwalnya, kedua adalah Strategi Pelaksanaanyaitu ceramah yang disampaikan oleh Da'i dengan memakai narasumber dilanjutkan dengan sesi tanya jawab dan diskusi antara penyiar dan narasumber, ketiga adalah Strategi Penilaian dengan menetapkan standar keberhasilan penyiar dan melakukan tahap koreksi terhadap program siaran dalam penyampaian dakwah.
\end{abstract}

Keywords:Strategi, RRI, Program 


\section{Pendahuluan}

Pesan-pesan dakwah dikelola dan dikemas dengan menggunakan berbagai cara atau strategi sehingga pesan dakwah memiliki dampak yang lebih besar. Dakwah yang baik, tentu disampaikan dengan cara atau strategi yang baik pula, salah satu cara yang tepat dalam berdakwah yakni dakwah dengan menggunakan media, baik itu media cetak maupun media elektronik, seperti: majalah, tabloid, buletin, artikel, radio, televisi, vcd, dan internet. Masingmasing media ini memiliki kelebihan dalam menyampaikan misi dakwah kepada masyarakat. ${ }^{1}$

Dari beberapa media tersebut, radio merupakan salah satu media yang dianggap efektif dalam menyampaikan program siaran dakwah, karena radio merupakan media informasi yang hingga sekarang masih memiliki cukup banyak audiensnya. Mengingat radio merupakan alat informasi yang fleksibel, kecil dan mudah dibawa kemana-mana, oleh sebab itu radio memiliki pengaruh yang lebih luas kepada pendengarnya. Dari sisi dakwah, ia dianggap media yang dekat dengan audiens untuk mengajakmenjalankan kebaikan serta meninggalkan keburukan (amar ma'ruf nahi munkar) ${ }^{2}$.

Disamping itu,radio memiliki beberapa keunggulan menurut Helena Olili diantaranya:

1. Radio memiliki dampak terhadap imajinasi pendengar. Radio

${ }^{1}$ Aliyudin Enjang AS, Dasar-dasar Ilmu Dakwah, (Bandung: Widya Padjajaran, 2009), hlm. 94

${ }^{2}$ Muhammad Arifin, Dakwah Multi Media, (Surabaya:Graha Ilmu Media, 2006), hlm. 75 . mampu merangsang imajinasipendengar sehingga ide yang disampaikan oleh radio dapat dikembangkan

2. Radio merupakan media yang murah

3. Radio mudah dibawa

4. Produksi program radio tidak terlalu mahal

5. Program radio dapat disebarluaskan secara massif

6. Pesan komunikasi radio dianggap cepat sampai

7. Radio dapat dipercaya sebagai sumber berita. ${ }^{3}$

Tambahan lagi, radio sebagai media memiliki beberapa kelebihan, diantaranya; ia dapat menjangkau jumlah khalayak sasaran yang besar pada waktu yang bersamaan,menjangkau individu manusia atau kelompok masyarakat yang tinggal di daerah terpencil, hidup terpencar-pencar dan menghadapi berbagai masalah geografis, pesan-pesannya mudah dimengerti dalam penertian ia tidak memerlukan kemampuan membaca yang memang belum banyak dimiliki sebagian besar masyarakat Indonesia. $^{4}$

Selanjutnya, dilihat dari segi format, menurut Pringle-StarrMcCavitt, seperti yang dikutip oleh Morissan, bahwa seluruh format stasiun radio dapat dikelompokkan kedalam tiga jenis, yaitu:

1. Format musik;ini merupakan format yang paling umum

${ }^{3}$ Helena Olili Waharsono, Berita Dan Informasi Jurnalistik Radio, (Jakarta: PT Indeks, 2007), hlm. 8.

${ }^{4}$ Sidhik Fajar Rini S, Pengelolaan Program Siaran Dakwah di Radio Mentari Kota Pekanbaru, (Pekanbaru: Jurnal Skripsi, 2011), hlm. 4 
digunakan oleh mayoritas radio komersial.

2. Format informasi; format ini dikelompokan menjadi dua bagian, yakni informasi yang didominasi berita (all news) dan informasi yang didominasi perbincangan (talk news), seperti berita lokal, regional dan nasional.

3. Format khusus (specialty); format ini merupakan format yang dikhususkan untuk audien berbasis etnis dan agama. Dengan demikian format khusus ini dapat dibagi lagi menjadi dua bagian, yaitu format khusus etnis dan format khusus agama. ${ }^{5}$

Dakwah yang di sampaikan lewat radio terletak pada format yang khusus (specialty). Ia memiliki ciri khas tersendiri yang biasanya memiliki orientasi yang jelas dan terarah yakni orientasidakwah. Sementara itu, salah satu Radio terkenal di Indonesia yang awalnya dikelola pemerintah ialah Radio Republik Indonesia atau yang disingkat dengan RRI. RRI sebagai media publik turut berperan dalam mengedukasi masyarakat muslim. Salah satu program penting RRI yang bertujuan khusus dalam aspek agama adalah program-program dakwah Islam. Dalam sejarah Radio Republik Indonesia, misalnya RRI Jakarta, ketika masa Orde Baru, menjadi sangat terkenal dengan acara siaran "Kuliah Shubuh" yang

\footnotetext{
${ }^{5}$ Morissan, Manajemen Media Penyiaran: Strategi Pengelola Radio dan Televisi, (Jakarta: Prenada Media Group, 2009), hlm. 168.
}

diselenggarakan oleh almarhum Buya Hamka. ${ }^{6}$

Dakwah melalui radio tersebut cukup populer dan digemari audiens karena program-programnya beragam, seperti 'Hikmah Fajar', 'Di Ambang Fajar". Semua program ini membawa pesan dakwah yang dibawakan oleh para da'i yang terkemuka pada saat itu. ${ }^{7}$ Salah satu stasiun Radio Republik Indonesia yang ada di Kota Pekanbaru ialah RRI Pekanbaru yang beralamat di Jalan Jendral Sudirman Pekanbaru.RRI Pekanbaru merupakan cabang dari RRI Jakarta.Ia merupakan lembaga penyiaran publik lokal dan milik pemerintah yang ada di kota Pekanbaru. Stasiun radio inimemiliki 4 Programa yaitu: Programa 1 untuk pendengar di provinsi, kota dan kabupaten. Pendengar programa ini memiliki status sosial yang sama dan ia mengudara pada Frekuensi 99,1 MHz. Programa 2 ditujukan untuk segmen Remaja, yaknipendengar yang berusia 12-25 tahun. Ia ditujukan khusus untuk pendengar yang tinggal di wilayah kota dan sekitarnya sehingga ia ditujukan khusus untuk pendengar yang memiliki status sosial menengah keatas. Ia mengudara pada Frekuensi $88,4 \mathrm{MHz}$. Sedangkan Programa 3 yang mengudara pada Frekuensi 91,2 $\mathrm{MHz}$. Program-programnya hanya fokus pada Berita, Informasi, dan Pendidikan. Sasaran khalayak programa ini adalah pendengar yang berusia 30-45 tahun dengan latar

\begin{tabular}{lrr}
\hline${ }^{6}$ Samsul Munir, & Rekonstruksi \\
Pemikiran Dakwah Islam & (Jakarta: \\
AMZAH, 2008), hlm. 189. & \\
${ }^{7}$ Samsul Munir, & Rekonstruksi \\
Pemikiran ... hlm. 190. &
\end{tabular}


belakang Pendidikan SLTA ke atas. Programa ini ditujukan kepada pendengar yang tinggal baik di kota dan pedesaan tanpa memandang status sosial. Siaran Programa 3 disiarkan langsung dari Pusat Jakarta. Programa 4 yang mengudara di Frekuensi 93,3 MHz fokus pada siaran kebudayaan dan hiburan Melayu untuk menumbuhkan kecintaan dan bangga terhadap kebudayaan Melayu. ${ }^{8}$

RRI Pekanbaru sebagai media publik milik Pemerintah, tidak hanya milik komunitas Muslim, tetapi juga milik komunitas masyarakat Non Muslim. Oleh karena itu RRI Pekanbaru diharapkan memiliki strategi yang tepat dalam menyampaikan program siaran dakwah kepada khalayak ramai agar tidak melanggar tatanan toleransi antar umat beragama di Kota Pekanbaru,.Dengan demikian, program dakwah Islam RRI tetap berjalan secara harmonis di tengah perbedaan keyakinan di tengah masyarakat.

Jenis penelitian ini dalam artikel ini adalah deskriptif,sedangkan pendekatan yang digunakan dalam kajian ini adalah pendekatan kualiatif. Karakter penelitian deskriptif dalam artikel ini adalah pendeskripsian atas realitas sosial yang menjadi objek kajian, dan berupaya menarik realitas itu ke permukaan sebagai suatu ciriatau " gambaran tentang kondisi, situasi ataupun fenomena tertentu." 9

${ }^{8}$ Radio RRI, Dokumen Profile RRI Pekanbaru, 2013.

${ }^{9}$ Burhan Bungin, Penelitian Kualitatif( Jakarta : Kencana, 2007), hlm. 68.

\section{Dakwah Melalui Radio}

Salah satu media yang bisa digunakan dalam kegiatan dakwah adalah radio. Hampir seluruh radio di Indonesia menyajikan informasi, edukasi, dan hiburan, serta siaran keagamaan sebagai bagian dari fungsi edukasi. Pemanfaatan radio sebagai media dakwah merupakan upaya menyampaikan pesan dakwah.Memanfaatkan radio sebagai alat dakwah merupakan upaya yang logis seiring dengan besarnya jumlah pendengar atau audiens yang dapat dijangkau sebagai sasaran dakwah (mad'u). ${ }^{10}$ Tidak heran jika IKMI Riau juga melakukan upaya pengembangan dakwah melalui radio IKMI yang mengudara di 90,8 FM. Beberapa program yang disiarkan oleh radio dakwah IKMI Riau adalah; program murattal al-Qur'an, Syiar al-Hikmah dan Mutiara Agama. ${ }^{11}$

Dalam melakukan aktifitas dakwahnya, da'i semestinya memperhatikan hal-hal yang berkaitan dengan karakteristik media ini yang memiliki perbedaan dengan media lain. Beberapa karakteristik radio siaran, diantaranya; siaran radio hanya dapat didengar (audialhearable), bahasa yang digunakan melalui radio seharusnya bahasa tutur, pendengar radio memiliki kecenderungan berada dalam kondisi santai, pendengar kemungkinan dalam keadaan mengemudi mobil, sedang tiduran, sambil bekerja di

\begin{tabular}{lcr}
\hline${ }^{10}$ Syamsul & Munir, & Rekonstruksi \\
Pemikiran & Dakwah & Islam, \\
(Jakarta:Amzah,2008), hlm. 189. & \\
11 Imron Rosidi dan Muhammad \\
Yusuf, " Upaya IKMI Kota Pekanbaru \\
dalam Pengembangan Dakwah", Idarotuna, \\
Vol. 1. No. 1.Oktober 2018.h. 16-24
\end{tabular}


kantor dan sebagainya.Siaran radio juga mampu mengembangkan daya imajinatif, dan komunikasi siaran radio cenderung bersifat satu arah. ${ }^{12}$

Sebagai media komunikasi, siaran radiobisa dianggap efektif dalam menyampaikan pesan-pesan komunikasi kepada pendengar. Hal ini karena: ${ }^{13}$

1) Memiliki daya langsung

Pesan dakwah dapat disampaikan secara langsung kepada khalayak,dalam pengertian, proses penyampaiannya tidak begitu kompleks. Pesan dakwah dapat langsung diterima di ragam tempat; di kantor, di kamar, di sawah, di mobil, dan lain-lain. Radio dapat menyiarkan suatu kejadian langsung dari lokasi kejadian (on the spot reporting).Saat ini teknik penyiaran radio mulai berkembang pesat.Komunikasi langsung antara pendengar radio dan da'i yang berdakwah di radio bisa dilakukan melalui system phone in program.Pendengar bisa menghubungi langsung da'i yang sedang mengudara melalui hubungan telepon untuk menanggapi atau menanyakan sesuatu kepada da'i sehingga pertanyaan pendengar bisa langsung dijawab oleh da'i tersebut.Pertanyaan dan jawaban tersebut bisa didengar oleh seluruh pendengar.

2) Memiliki daya tembus

Siaran radio memiliki daya jangkau wilayah yang luas.Semakin kuat pemancar

\footnotetext{
${ }^{12}$ Syamsul Munir, Rekonstruksi Pemikiran ... hlm. 190.

${ }^{13}$ Ibid, hlm.191.
}

radionya maka semakin jauh daya jangkau jaraknya.Pemancar yang bergelombang pendek (short wave) dengan daya 500- $1000 \mathrm{~kW}$ dengan arah antena tertentu bisa menjangkau pendengar di seluruh dunia.

3) Memiliki daya tarik

Daya tarik khusus dari media radio adalah terintegrasinya suara manusia, suara musik, dan bunyi tiruan (sound effect) sehingga dapatmerangsang daya imajinasi pendengarnya. Sebuah sandiwara radio yang dikemas sedemikian rupadapat menarik pendengarnya.Dengan

demikian,berdakwah dengan mempergunakan paket produksi sandiwara radio bisa cukup efektif meningkatkan minat pendengar radio terhadap misi dakwah yang dilakukan.

\section{Strategi Penyampaian Pesan Dakwah}

Strategi penyampaian pesan dakwah merupakan" suatu pola pikir dalam merencanakan suatu kegiatan mengubah sikap, sifat, pendapat, dan perilaku khalayak (komunikan, hadirin, atau mad'u), atas dasar skala yang luas melalui penyampaian gagasan-gagasan." ${ }^{14}$ Secara umum strategi dalam penyampaian pesan dakwah terdiri dari beberapa tahapan atau strategi, diantaranya ${ }^{15}$ :

1) Strategi perencanaan meliputi pengumpulan informasi (data) dan asumsi kebutuhan mad'u. Strategi

\footnotetext{
${ }^{14}$ Kustadi Suhandang, Strategi Dakwah: Penerapan Strategi Komunikasi dalam Dakwah, (Bandung: PT Remaja Rosdakarya, 2014), hlm. 84.

${ }^{15}$ Kustadi Suhandang, Strategi Dakwah; Penerapan ... hlm.85.
} 
ini juga mencakup penentuan atau pembatasan masalah pesan yang akan disampaikan, menentukanobjek dan tujuan pesan dakwah yang disampaikan, menyusun atau merumuskan strategi atau cara-cara dalam menyampaikan pesan dakwah. Strategi ini juga termasukpemilihan media sebagai sarana penyampaian pesan dakwah, memutuskan standar pelaksanaan dan pengukuran dan sebagainya.

2) Strategi

pelaksanaanmencakupkegiatan-

kegiatan pelaksanaan atau penerapan-penerapan dari segala sesuatu yang telah direncanakan. Strategi pelaksanaan merupakan implementasi strategi-strategi yang telah dirumuskan dalam pencapaian tujuan yang telah ditetapkan. Strategi ini meliputi jadwal pelaksanaan, petugas pelaksana, tempat pelaksanaan, cara atau strategi yang digunakan dan lain sebagainya.

3) Strategi penilaian atau pengukuran merupakan tahapan terakhir dalam strategi penyampaian pesan dakwah. Strategi ini bertujuan menilai atau mengukur pelaksanaan berbasis standar ukuran pelaksanaan yang telah direncanakan dalam rangka pencapaian tujuan yang telah dirumuskan.

\section{Strategi Radio Republik Indonesia (RRI) Pekanbaru Dalam Menyampaikan Program Siaran Dakwah}

Data yang disajikan pada artikel ini berbasis hasil wawancara dan observasi serta didukung dengan dokumentasi terkait.Wawancara dilakukan dengan cara mengajukan beberapa pertanyaan mengenai staregi Radio Republik Indonesia dalam menyampaiakan pesan-pesan dakwah kepada pendengarnya.Selanjutnya, juga dilakukan observasi dengan cara mengamati fakta tentang Strategi Radio Republik Indonesia dalam menyampaikan program siaran dakwah kepada pendengar atau masyarakat guna memperkuat hasil wawancara. Dan selanjutnya disajikan data yang telah didapat sebagai berikut :

\section{Strategi Perencanaan}

Strategi perencanaan atau planning merupakan salah satu bagian dari unsur manajemen yang terkait dengan pengambilan keputusan untuk masa depan, baik jangka panjang maupun jangka pendek. Strategi ini meliputi ; apa, siapa, bagaimana, kapan, dimana, dan berapa, baik sehubungan dengan dakwah yang disampaikan.

Dalam menyampaikan dakwah perlu perencanaan yang matang agar dakwah yang disampaikan menjadi efektif dan efesien. Penyampaian dakwah diharapkan bisa dilakukan di berbagai situasi dan kondisi. Dalam era modern seperti saat ini, dakwah pada dasarnya bisa disampaikan dengan memanfaatkan jaringan sosial media ataupun media berbasis elektronik yang berkembang pada saat ini. Radio misalnya merupakan media elektronik yang bisa digunakan dalam menyampaikan pesan-pesan dakwah. 
Mengenai perencanaan dalam menyampaikan program siaran dakwah melalui radio, Fitrayati mengatakan bahwa perencanaan dalam menyampaikan dakwah melalui radio merupakan suatu langkah awal yang dirasa penting untuk dirancang. Hal ini karena apa yang disampaikan harus tepat dan cocok serta faktual terhadap perkembangan atau problem yang terjadi dimasyarakat. Di RRI pekanbaru sendiri strategi yang digunakan dalam proses merencanakan kegiatan penyiaran ialah yang pertama, menetapkan tema ataupun topik yang ingin disampaikan. Kedua, menetapkan penyiar yang mahir dalam membawakan program siaran dakwah seperti Ustadz atau Ustadzah yang direkomendasi dari MUI.Ketiga, menetapkan jadwal penyiaran yang ingin dimasukkan nuansa dakwah didalamnya. Dan keempat, menentukan lokasi yang ingin disiarkan terkhusus dikota pekanbaru. $^{16}$

Wawancara dengan Harun Alrosid mengatakan bahwa dalam proses penyampaian program siaran dakwah melalui radio hal yang pertama yang dilakukan adalah menetapkan tema. Tema yang ditetapkan harus berdasarkan kebutuhan masyarakat pada saat ini sesuai dengan fenomena yang terjadi dimasyarakat. Yang disampaikan tentunya bersumber dari Al-Qur'an dan Hadist. Tema yang ditetapkan ini bertujuan untuk memberikan pencerahan kepada pendengar agar

${ }^{16}$ Fitrayati, Wawancara, tanggal 29 Maret 2017 Pukul 17:03 WIB. dapat menambah pengetahuan dalam ilmu agama. ${ }^{17}$

Berdasarkan wawancara dengan Teguh Heriyanto, tema yang ditetapkan tersebut harus menjurus kepada yang dibutuhkan pendengar, artinya dakwah yang disampaikan bukan hanya sekedar pesan yang terbuang akan tetapi melekat kepada hati pendengar. Maka dari itu tema yang dipilih harus benar-benar matang dan memang dibutuhkan oleh pendengar. ${ }^{18}$

Mengenai penetapan penyiar, Fitrayati mengatakan penyiar siaran dakwah yang dipilih adalah penyiar yang mempunyai kompetensi dalam berdakwah dan bisa membawakan siaran dakwah secara baik dan benar. Selain itu dipilih juga ustadz atupun ustadzah yang memang memiliki kualitas dakwah yang mumpuni untuk melakukan penyiaran yang telah didtetapkan. Mereka dipilih oleh RRI melalui rekomendasi MUI. Da'i yang dipilih berasal dari beragam organisasi dakwah di Pekanbaru seperti MDI, IKMI ataupun IKADI.$^{19}$

Penyiar harus membawakan siaran dakwah sesuai kondisi atupun waktu yang tepat. Noni Andini mengatakan bahwa dalam menyampaikan program siaran dakwah RRI menetapkan waktu yang cocok untuk pendengar. Waktu yang tepat didasarkan pada kebutuhan pendengar terhadap pesan-pesan yang disampaikan, seperti sehabis

\footnotetext{
${ }^{17}$ Harun Alrosid, Wawancara, tanggal 31 Maret 2017 Pukul 20:38 WIB.

${ }^{18}$ Teguh, Wawancara,tanggal 30 Maret 2017 Pukul 12.00 WIB.

${ }^{19}$ Fitrayati, Wawancara, tanggal 31 Maret 2017 Pukul 11:37 WIB.
} 
sholat fardhu dan juga hari-hari besar Islam.

Contoh penyiaran dakwah yang dilakukan berbasis perhitungan waktu dan temap adalah Bincang Sore Genius atau Generasi Muda Islam. Konsep program ini bersifat bincang (talk show), pengisinya ramai, konsepnya santai, dan sesuai dengan anak muda. Program ini juga dilanjutkan dengan program malam yang disebutReligi Nite. Setiap pekan, konsepnya berbeda-beda. Untuk pekan pertama tahsin AlQur'an atau memperbaiki bacaan AlQur'an yg di bawakan oleh ustadz atau guru remaja mesjid mutmainnah atau kajian bersama ustadz. Pekan kedua lembaran siroh atau menyimak siroh dari sahabat atau sohabiyahnya RosulullahSAW. Pekan keempat dan kelima masih kajian dari remaja mesjid mutmainnah yaitu dua orang akhwat dan ikhwat. Konsepnya lebih serius dan formal. Kemudian juga RRI memiliki programpersembahan nasyid baik itu di acara event-event, walimah, keagamaan, dan pemerintah. Program ini biasanya berisi hiburan nasyid dan juga teater Islami. $^{20}$

"Konsep bincang-bincang dan ceramah yang dilakukan saat ini juga berkelanjutan sebagai bahan untuk pendengar menyimak ataupun memahami apa yang dibicarakan.Konsep ini merupakan konsep dakwah yang khusus untuk para mad'u di radio". ${ }^{21}$

Gozali Ardi menambahkan, selain menetapkan waktu yang tepat,

\footnotetext{
${ }^{20}$ Noni Andini, Wawancara,tanggal 30 Maret 2017 Pukul 18:21 WIB.

${ }^{21}$ Noni Andini, Wawancara,tanggal 31 Maret 2017 Pukul 16:20 WIB.
}

lokasi yang ditetapkan juga memiliki pengaruh bagi pendengar untuk meresapi dakwah yang disampaikan. Tempat yang disiarkan pada umumnya dipekanbaru. Hal itu terkhusus dilakukan dipusat kota dan juga daerah yang banyak memakai jaringan radio yang beredar dijaringan media massa. Hal ini berfungsi untuk mengoptimalkan program siaran dakwah yang disampaikan dengan harapan merubah paradigma masyarakat agar mengamalkan ajaran Islam yang lebih Kaffah. ${ }^{22}$

Supriyanto berpendapat bahwa RRI dalam menyampaikan program siaran dakwah melalui radio cukup memenuhi persyaratan dan mempengaruhi pendengar secara positif, kemudian juga pesan yang disampaikan terkonsep dan mudah dipahami secara menyeluruh. ${ }^{23}$

Dengan demikian, strategi perencanaan penyampaian siaran dakwah melalui radio dilakukan dengan beberapa langkah.Pertama, menetapkan tema ataupun topik yang ingin disampaikan. Kedua, menetapkan penyiar dan ustadz serta ustadzah yang mahir dalam membawakan siaran dan menyampaikan siaran dakwah yang direkomendasikan oleh MUI. Ketiga, menetapkan jadwal penyiaran yang ingin dimasukkan nuansa dakwah didalamnya. Dan keempat, menentukan lokasi yang ingin disiarkan terkhusus di kota pekanbaru.Hal ini sejalan dengan pendapat Fred R. David bahwaperumusan strategi mencakup

\footnotetext{
${ }^{22}$ Gozali Ardi, Wawancara, tanggal 30 Maret 2017 Pukul 21:39 WIB.

${ }^{23}$ Suprianto, Wawancara,tanggal 20 Maret 2017 Pukul 14.00 WIB.
} 
penetapan visi dan misi, identifikasi peluang dan ancaman eksternal suatu organisasi, penetapan tujuan jangka panjang, pencarian strategi-strategi alternatif, dan pemilihan strategi tertentu untuk mencapai tujuan. ${ }^{24}$

Menetapkan tema merupakan sesuatu yang sangat perlu karena temamenjadi basis alasanpara pendengar untuk mendengarkan siaran radio tersebut.Tema yang menarik akan menghasilkan pengaruh bagi para pendengar untuk mendengarkan siaran dakwah yang disampaikan. Terkadang tema juga yang menjadi bahan isi dari proses penyiaran.

Begitu juga dengan penetapan penyiar,hal ini berpengaruh terhadap isi atau siaran dakwah yang disampaikan. Penyiar yang berkompeten akan menyampaikan dakwah secara efektif dan efisien kepada mad'u yang mendengarkan.Sama halnya dengan waktu dan lokasi penyiaran, juga mempengaruhi efektifitas dakwah RRI.

\section{Strategi Pelaksanaan}

Strategi pelaksanaan merupakanupaya yang dilakukan untuk mewujudkan semua rencana dan kebijaksanaan yang telah dirumuskan dan ditetapkan. Strategi ini mencakup implementasi berbagai hal seperti segala kebutuhan alat-alat yang diperlukan, siapa yang akan melaksanakan,dimana tempat pelaksanaannya dan kapan waktu dimulainya. Hal penting yang harus diperhatikan agar pelaksanaan dapat mencapai tujuan, maka tujuan harus

24 Fred R. David, Manajemen Strategis: Konsep, (Jakarta: Salemba Empat, 2009), hlm. 6.

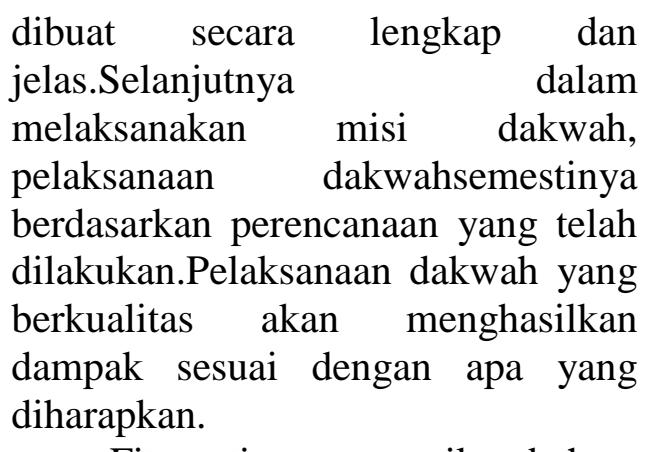

Fitrayati menyampaikan bahwa pelaksanaan penyiaran dakwah di RRI pekanbaru itu dilakukan dengan penyampaian melalui ceramah dan bincang-bincang. Isi ceramah (Bil Lisan) pada umumnya ilmu agama dan himbauan amar ma'ruf nahi munkar dan meningkatkan kualitas seorang hambanya kepada Allah melalui solat.Ceramah juga menyampaikan contoh suri tauladan agar lebih mudah di cerna dan di contoh oleh audiens. ${ }^{25}$

Gozali Ardi juga menambahkan dalam ceramah juga dilakukan tiga sesi, yang pertama pengupasan materi, kemudian dilanjutkan dengan tanya jawab, dan diakhiri kesimpulan, lalu ditutup dengan nasyid. Dan pelaksanaan penyampaian materi dakwah diambil dari Al-Qur'an dan Hadist, serta dari koleksi Pimpinan yang juga banyak mengarang buku agama lebih dari 60 buku dan sajak atau puisi Islami yg ribuan buku telah di cetak dan dijadikan sumber penyampaian dakwah dalam penyiaran. ${ }^{26}$

Noni Andinimengatakan bahwa pelaksanaan penyampaian program siaran dakwah dikategorikan berdasarkan topiktertentu.Ada empattopik besar

${ }^{25}$ Fitrayati, Wawancara,tanggal 15 Maret 2017 Pukul 10:10 WIB.

${ }^{26}$ Gozali Ardi, Wawancara,tanggal 18 Maret 2017 Pukul 11:20 WIB. 
yang biasanya disampaikan dalam program siaran yaitutopik berdasarkan perayaan hari besar Islam, misalnya momen Maulid Nabi Muhammad Saw, maka temanya juga tentang Maulid Nabi Muhammad Saw.Topik berkaitan dengan Hari Nasional misalnya tema Pendidikan, 17 Agustus Proklamasi, makna Perjuangan Pahlawan.Topik ketiga terkait isu-isu terkini misalnya tentang penistaan agama maka itu akan dibahas, atau dalam pemilihan pemimpin, kebakaran hutan dan berkaitan dengan nilai-nilai keislaman. Topik keempat biasanya terkait dengan topic ringan tetapi menyentuh hati pendengar. ${ }^{27}$

Teguh Heriyanto juga menyampaikan bahwa selain pelaksanaan dari segi materi dakwah dan ceramah. Strategi pelaksanaan juga dilakukan melalui bincangbincang (talk show) sebagai program unggulan dakwah radio.Dalam program ini, bincang-bincang antara narasumber dengan penyiar disiarkan secara langsung mealui radio RRI. Nama program ini disebut program Bincang Sore Genius atau Generasi Muda Islam yang di isi oleh forum Silaturohim remaja mesjid mutmainnah dan Religi Nite. ${ }^{28}$

Menurut Harun Alrosid yang harus diperhatikan terlebih dahulu dalam pelaksanaan penyampaian program siaran dakwah adalahkeharusan setiap narasumber minimal 3 kali briefing sebelum menyampaikan materi siaran, untuk membahas skema, membahas

\footnotetext{
${ }^{27}$ Noni Andini, Wawancara,tanggal 18 Maret 2017 Pukul 10:20 WIB.

${ }^{28}$ Teguh

Heriyanto, Wawancara,tanggal 17 Maret 2017 Pukul 09:10 WIB.
}

kerangka, materi, hadits yang ingin dipublikasikan. ${ }^{29}$

Nurhayati juga menyampaikan bahwa pelaksanaan kegiatan melalui bincang-bincang dengan narasumber dan ceramah melalui tanya jawab yang dilakukan oleh Ustadz merupakan metode penyampaian yang sangat dominan.Hal ini karena siaran dakwah yang diberikan dalam kedua model inidianggap lebih efektif dan berpengaruh kuat. ${ }^{30}$

Dalam melaksanakan proses penyampaian program siaran dakwah yang dilakukan terdapat tiga sesi pokok;pertama, pengupasan materi, kemudian dilanjutkan dengan tanya jawab, dan diakhiri kesimpulan, dan di tutup dengan nasyid. Pelaksanaan penyampaian materi dakwah itu disokong oleh sumber rujukan yang diambil dari Al-Qur'an dan Hadist.

Kustadi Suhandang menyatakan bahwa pelaksanaan dari strategi-strategi yang telah dirumuskan dalam perencanaan yang telah ditetapkan biasanya meliputikeseluruhan pelaksanaan mulai tugas pelaksana waktu ataupun sarana dan prasarana. ${ }^{31}$

Tahap penyiaran yang dilakukan melalui ceramah di RRI Pekanbaru merupakan proses penyampaian dakwah sebagi mana mestinya. Dengan narasumber ustadz ataupun ustadzah penyampaian ceramah dapat dilakukan dengan mengutarakan ajaran Islam AlQur'an dan Hadist. Begitu juga dengan bincang bincang yang

${ }^{29}$ Harun, Wawancara,tanggal 16 Maret 2017 Pukul 09:35 WIB.

${ }^{30}$ Nurhayati, Wawancara, tanggal 20 Maret 2017 Pukul 14:10 WIB.

${ }^{31}$ Kustadi Suhandang, Strategi Dakwah; Penerapan ... hlm.85. 
dilakukan oleh penyiar, narasumber dapat memberikan pemahaman kepada pendengar secara jelas bagaimana Islam yang diajarkan melalui siaran-siaran dakwah tersebut.

Penyiaran RRI tentang program siaran dakwah adalah bersifat interaktif artinya saling mendengar dan memahami.Hal ini cukup penting bagi impelementasi proses komunikasi efektif. Model interaktif juga akan lebih memudahkan pemahaman mad'u atau pendengar radio tersebut.

Dengan demikian, dapat disimpulkan bahwa strategi yang dilakukan RRI dalam proses pelaksanaan penyampaian program siaran dakwah adalah sebagai berikut; penyampaian dilakukan melalui ceramah oleh narasumber dan sesi tanya jawab dengan pendengar, penyampaian dilakukan dengan bincang-bincang antara penyiar dengan narasumber untuk membahas materi dakwah yang disampaikan, serta penyampaian pesan dakwah juga melalui tahsin Al-Qur'an dan Nasyid Islami sebagi penutup penyiaran.

\section{Strategi Penilaian}

Strategi penilaian merupakan rangkaian cara untuk mendapatkan dan menerjemahkan data yang dilakukan secara sistematis dan berkelanjutan sehingga menjadi sumber rujukan dalam pengambilan keputusan.Penilaian berhubungan erat dengan proses evaluasi dalam suatu kegiatan. Ia dilakukan untuk memperoleh data atau informasi sebelum dilakukan sebuah keputusan. Dalam konteks penilaian atau evaluasi, semua strategi terbuka untuk dimodifikasi di masa yang akan datang karena berbagai faktor eksternal dan internal yang terusmenerus berubah.

Mengenai penilaian ataupun evaluasi yang dilakukan diRRI terhadap kegiatan dakwah yang disiarkan, Fitrayati mengatakan bahwa RRI menetapkan standar atau tolak ukur untuk melihat bahwa dakwah yang disampaikan berhasil atau tidak kepada pendengar. Kemudian juga mengukur kinerja penyiaran dan pengambilan langkah korektif terhadap kegiatan yang telah dilakukan. ${ }^{32}$

Teguh

jugamengatakan bahwa evaluasi yang dilakukan melalui penetapan standar atau tolak ukur. Hal ini dilakukan dengan cara RRI melakukan peninjauan keberhasilan dengan melihat kuantitas pendengar radio mengenai program siaran dakwah yang disiarkan. Jikalau banyak pendengar yang mendengarkan otomatis evaluasi dilakukan hanya sebatas penambahan ataupun alternatifide-ide baru yang dimunculkan dan akan tetapi jikalau terlihat kuantitas pendengar yang sedikit hal ini dilakukan evaluasi yang menyeluruh terhadap penyiar maupun cara materi yang disampaikan. ${ }^{33}$

Herman menilai bahwasanya RRI adalah sarana penyampaian informasi yang efektif, program penyampaian yang dilakukan juga bermanfaat bagi pendengar, apalagi yang berbau program dakwah, hal

${ }^{32}$ Fitrayati, Wawancara,tanggal 15 Maret 2017 Pukul 10:20 WIB.

${ }^{33}$ Teguh

Heriyanto, Wawancara,tanggal 17 Maret 2017 Pukul 09:30 WIB. 
tersebut tentu memberikan pengaruh besar terhadap pemikiran dan transfrer ilmu tentang ajaran Islam yang baik. RRI dirasa cukup berperan penting dalam menyiarkan program siaran dakwah di pekanbaru. $^{34}$

Noni Andini juga menambahkan bahwa penilaian yang dilakukan juga terhadap kinerja penyiaran. Adakah penyiar yang belum memenuhi kompetensi dalam menyampaikan siaran dakwah ataukah sudah memiliki kompetensi. Jika terdapat hal yang demikian RRI melakukan perbaikan terhadap apa yang menjadi kekurangan dari proses penyampaian dan juga kekurangan dari metode penyampaian. ${ }^{35}$

Harun

Alrosid

berpendapatbahwa dalam penilaian yang terpenting adalah tindakan korektif yang dapat merubah kegiatan lebih optimal. Korektif yang dilakukan harus menyeluruh mulai dari materi, penyiar, waktu, hingga lokasi pendengar. Hal ini dilakukan untukmemaksimalkan kinerjayang mungkin menjadi patokan bagi setiap Radio. Koreksi dilakukan setelah melihat kinerja yang dilakukan tidak efektif dan tidak mencapai standar atau tolak ukur yang ditetapkan. ${ }^{36}$

Supriyanto, sebagai pendengar aktif RRI,mengatakan bahwa memandang program RRI dalam penyampaian siaran dakwah adalah program yang sangat memacu pendengar untuk mendengar, sejauh ini siaran-siaran dakwah positif bagi

\footnotetext{
${ }^{34}$ Herman, Wawancara,tanggal $\quad 16$ Maret 2017 Pukul 09:40 WIB.

${ }^{35}$ Noni Andini, Wawancara,tanggal 18 Maret 2017 Pukul 10:25 WIB.

${ }^{36}$ Harun Alrosid, Wawancara, tanggal 16 Maret 2017 Pukul 09:45 WIB.
}

pendengar yang mendengarkan. Sebagian orang merasakan bahwa siaran dakwah yang disampaikan sangat bermanfaat. ${ }^{37}$

"Siaran-siarandakwah di RRI adalah hal yang Positif bahkan banyak dikalangan ibu-ibu pendengar agar anak-anaknya juga berkontribusi dalam menyiarkan dakwah, jadi memotivasi orang tua agar anaknya lebih dekat dengan agama. Ada juga penelpon muda yg bergabung yg sifatnya silaturahim dia via telpon ada tanya jawab dan lain sebagainya. Hal ini tentu suatu yang bermanfaat bagi mad' $u .{ }^{38}$ Abdul Razak selaku tokoh agama sekaligus pendengar program siaran dakwah RRI mengatakan bahwa RRI sudah baik dalam menyampaikan program siaran dakwah hanya saja memerlukan banyak jam tayang agar perlu diperbanyak, supaya disetiap hari selalu ada pesan-pesan dakwah yang perlu di dengar bagi mad'u. Hal ini karena yang namanya pendengar selalu butuh informasi di sela-sela istirahatnya apalagi ilmu agama yang sangat penting. ${ }^{39}$

Di RRI Pekanbaru proses penilaian dalam program kegiatan penyampaian siaran dakwah adalah menetapkan standar atau tolak ukur untuk melihat bahwa dakwah yang disampaikan berhasil atau tidak kepada pendengar. Kemudian juga

${ }^{37}$ Suprianto, Wawancara, tanggal 20 Maret 2017 Pukul 14:10 WIB.

${ }^{38}$ Nurhayati, Wawancara,tanggal 20 Maret 2017 Pukul 14:20 WIB.

${ }^{39}$ Abdul Razak, Wawancara,tanggal 20 Maret 2017 Pukul 14:20 WIB. 
mengukur kinerja penyiaran dan pengambilan langkah korektifterhadap kegiatan yang telah dilakukan.RRI melakukan peninjauan keberhasilan pelaksanaan siaran dakwah dengan melihat kuantitas pendengar radio mengenai program siaran dakwah yang disiarkan. Jikalau banyak pendengar yang mendengarkan otomatis evaluasi dilakukan hanya sebatas penambahan ataupun alternatif ideide baru yang dimunculkan dan akan tetapi jikalau telihat kuantitas pendengar yang sedikit hal ini dilakukan evaluasi yang menyeluruh terhadap penyiar maupun cara materi yang disampaikan. Penilaian juga dilakukan terhadap kinerja penyiaran.

Fred R. Davidmenyatakan bahwa aktivitas penilaian strategi yang mendasar adalah (1) mereview faktor-faktor eksternal dan internal yang menjadi basis bagi strategi saat ini, (2) pengukuran kinerja, dan (3) pengambilan langkah korektif. Penilaian strategi, menurutnya, diperlukan karena apa yang berhasil saat ini tidak selalu berhasil di masamasa yang akan datang. Keberhasilan senantiasa menciptakan persoalan baru dan berbeda. Organisasi yang mudah berpuas diri akancenderung mudah mengalami kegagalan. ${ }^{40}$

Kustadi

Suhandang menyampaikan bahwa " penilaian merupakan tahapan terakhir dalam strategi penyampaian program siaran dakwah dengan tujuan menilai atau mengukur apakah pelaksanaan sesuai dengan standar ukuran pelaksanaan

${ }^{40}$ Fred R. David, Manajemen Strategis: Konsep, (Jakarta: Salemba Empat, 2009), hlm. 8. yang telah direncanakan dalam rangka pencapaian tujuan yang telah dirumuskan." 41

Berdasarkan pemaparan diatas, dapat disimpulkan bahwa strategi yang dilakukan RRI dalam proses penilaian adalah sebagai berikut; penetapan standar atau tolak ukur keberhasilan penyiaran dengan melihat kuantitas pendengar, melakukan pengukuran kinerja, mana yang efektif dan yang tidak efektif, dan melakukan tahap koreksi terhadap penilaian yang kurang baik dari program penyampaian siaran dakwah.

\section{Kesimpulan}

Berdasarkan data yang telah diperoleh melalui wawancara, observasi, dokumentasi yang dilakukan terhadap pihak-pihak setelah dilakukan analisis, maka dapat disimpulkan bahwa Strategi Radio Republik Indonesia (RRI) Pekanbaru dalam menyampaikan program siaran dakwah, dilakukan dengan 3 cara :

Pertama, strategi perencanaan
yang dilakukan dengan cara
;menetapkan tema atau topik yang
ingin disampaikan, menetapkan
penyiar yang mahir dalam
membawakan program dakwah,
menetapkan jadwal penyiaran yang
ingin dimasukkan nuansa dakwah
didalamnya serta menentukan lokasi
penyiaran.

Kedua, strategi pelaksanaan penyiaran yang dilakukan melalui ceramah oleh narasumber melalui sesi tanya jawab dengan pendengar dan penyampaian siaran dakwah

\footnotetext{
${ }^{41}$ Kustadi Suhandang, Strategi Dakwah; Penerapan ... hlm.86.
} 
dengan cara bincang-bincang antara penyiar dengan narasumber untuk membahas materi dakwah yang disampaikan serta melalui tahsin AlQur'an dan Nasyid Islami sebagai pesan dakwah.

Ketiga, strategi penilaian yang dilakukan dengan menetapkan standar atau tolak ukur keberhasilan penyiaran dengan melihat kuantitas pendengar dan melakukan pengukuran atas kinerja penyiarserta melakukan tahap koreksi terhadap penilaian yang kurang baik dari program penyampaian siaran dakwah.

\section{Daftar Pustaka}

Adnan Mahdi, Mujahidin . (2014). Panduan Penelitian Praktis untuk Menyusun Skripsi, Tesis dan Disertasi. Bandung : Alfabeta.

Al Barry,M. Dahlan. (tt)Kamus Ilmiah Populer. Surabaya: Arkola.

Arifin, Anwar. (1989).Strategi Komunikasi.Bandung: Armico.

Arifin,Muhammad. (2006).Dakwah Multi Media.Surabaya:Graha Ilmu Media.

Aziz, Ali. (2009).Ilmu Dakwah Edisi Revisi.Jakarta: Kencana.

Badadu, JS dan Zain,Sutan Muhammad. (1994).Kamus Bahasa Indonesia.Jakarta: Pustaka Sinar Harapan.

Bungin,Burhan. (2007).Penelitian Bungin, M. Kualitatif. Jakarta : Kencana. (2007).Penelitian Kualitatif: Komunikasi, Ekonomi, Kebijakan Publik dan Ilmu
Sosial Lainnya. Jakarta: Prenada Media Group.

David,Fred R. (2009). Manajemen Strategis:Konsep.

Jakarta:Salemba Empat.

Dokumen LPP RRI Pekanbaru

Enjang AS, Aliyudin.(2009).Dasardasar Ilmu

Dakwah.Bandung: Widya Padjajaran.

Gulo, W.(2004).Metodologi Penelitian.Jakarta: PT. Gramedia.

Hartono,Toni. Rosidi, Imron. Arwan dan Masduki. (2011). Komunikasi Dakwah. Pekanbaru: Yayasan Pusaka Riau.

Morissan. (2009).Manajemen Media Penyiaran: Strategi Pengelola Radio Dan Televisi. Jakarta: Prenada Media Group.

Munir,Samsul.

RekonstruksiPemikiran

Dakwah Islam. Jakarta: AMZAH.

Mustakim. (2015).Strategi Dakwah Produser pada Acara Dakwah Pagi di Radio Komunitas Induk Balerante 907 dalam Menyiarkan Islam di Wilayah Balerante Kelaten. Yogyakarta: Skripsi UIN Sunan Kalijaga.

Radio RRI. (2013).Dokumen Profile RRI Pekanbaru.

Rini S,Sidhik Fajar. (2011).Pengelolaan

Program Siaran Dakwah dI Radio Mentari Kota Pekanbaru. Pekanbaru: Skripsi UIN Suska Riau.

Rosidi, Imron dan Yusuf,Muhammad. (2018).“ Upaya IKMI Kota 
Pekanbaru dalam Pengembangan Dakwah", Idarotuna, Vol. 1. No. 1.h. 16-24.

Solehudin,Hasan. (2013). Strategi Komunikasi Dakwah Program Tausyiah Udara Radio Republik Indonesia 91,1 Mhz Yogyakarta Dalam Menyampaikan PesanPesan. Yogyakarta: Skripsi UIN Sunan Kalijaga.

Sugiyono. (2009). Memahami Penelitian Kualitatif. Bandung: Alfabeta.

Suhandang, Kustadi.(2014). Strategi Dakwah;Penerapan Strategi Komunikasi dalam Dakwah. Bandung: PT Remaja Rosdakarya.

Suharsimi dan Arikunto. (2006).Prosedur Penelitian Suatu Pendekatan Praktik.Jakarta: Rineka Cipta.

Supriyono,R.A. (1998).Manajemen Strategi dan Kebijakan Bisnis. Yogyakarta: BPFE Yogyakarta.

Suryabrata,Sumardi.

(1995).Metodologi

Penelitian.Jakarta: PT. Raja Grafindo Persada.

Suyadi, Prawirosentono, dan Primasari, Dewi. (2014).Manajemen Stratejik \& Pengambilan Keputusan Korporasi.Jakarta: PT Bumi Aksara.

Udin, Rafi dan Djaelani,Maman Abdul. (2001).Prinsip dan Strategi Dakwah.Jakarta: Pustaka Media.

Udin,Rafi'. (1992). Prinsip dan Strategi Dakwah. Bandung: Pustaka Media.
Waharsono,Helena Olili. (2007).Berita Dan Informasi Jurnalistik Radio.Jakarta: PT Indeks. 